\title{
Tourist Intensity in Capital Cities in Central Europe: Comparative Analysis of Tourism in Prague, Vienna and Budapest
}

\author{
Veronika Dumbrovská, Dana Fialová \\ e-mail: veronika.dumbrovska@natur.cuni.cz, dana.fialova@natur.cuni.cz
}

Department of Social Geography and Regional Development, Faculty of Science, Charles University in Prague, Czech Republic

Dumbrovská, V., Fialová, D. (2014). Tourist Intensity in Capital Cities in Central Europe: Comparative Analysis of Tourism in Prague, Vienna and Budapest. Czech Journal of Tourism, 3(1), 5-26. DOI: 10.2478/cjot-2014-0001.

\begin{abstract}
Urban tourism has become a significant phenomenon of tourism over the last decade. The importance of urban tourism has grown mainly due to the development of transport and information technologies. Rapid advancement of low cost airlines and reduction of administrative barriers owing to the expansion of the Schengen area caused not only the development of a number of urban destinations, including Prague, but also the growth of new source markets. This paper compares the development of urban tourism in Prague with the situation in Vienna and Budapest in the last decade. The aim of the paper is to describe the main trends of tourism development and the geographic distribution of tourism in Prague in comparison with culturally and historically similar cities - Vienna and Budapest. The analysis shows high load of tourism in Prague and its strong concentration in the old city. This causes congestion in the city centre and an extrusion of residential functions by the functions of tourism. As a result, a tourism ghetto has been formed in the centre of Prague and the urban society has been increasingly dualized.
\end{abstract}

\section{Keywords}

Prague, city, urban tourism, Vienna, Budapest

JEL classification: L83, L88, Q56 / Accepted: 30 May 2014 


\section{Introduction}

Urban tourism is a type of tourism with a long tradition, which could be traced back to one of the first organized trips, the so-called Grand Tour (Fainstein \& Judd, 1999). Nevertheless, the growth of urban tourism is connected with the end of industrial age and the beginning of the postindustrial age. An increased interest in urban tourism research coincides with this transformation.

Prague as the capital of the country that belonged to the so-called Eastern Bloc has entered the tourist market at the beginning of the 1990's. Despite this disadvantage, the development of tourism in Prague was rapid and Prague has become the city with the highest intensity of tourism among the capitals in Central Europe (Dumbrovská, 2013).

The aim of this paper is to compare tourism in Prague with tourism in Vienna and $\mathrm{Bu}$ dapest between 2003 and 2011. These cities were selected for their similarities in history, culture and volume of tourism. In this paper, the development of tourism in these cities, its geographical aspects, structure, seasonality and its change during the last decade are analyzed. For the comparison the authors used secondary data from national statistical bureaus of Czechia, Austria and Hungary, and from the international databases TourMIS and Eurostat.

\section{Urban tourism research}

Urban tourism had been neglected by academic research for a long time. At the end of 1980's, Ashworth (1989) "pointed out the double neglect of city tourism. Tourism researchers had neglected the city, though so much tourism took place there, and urbanists had neglected tourism, despite its rapid growth and increasing influence on cities." (cited in Maitland, 2010, p. 1). Edwards, Griffin, and Hayllar (2008, p. 1034) describe research of urban tourism prior 1980's as "fragmented and not recognized as distinct field."

Since 1980's, tourism in cities has started growing rapidly in connection with deindustrialization. Most of the cities transformed from the places of production to the places of consumption. Urban tourism played a significant role in this process. It allowed a smooth transition of formerly industrial labor to tertiary sector, mostly without any retraining schemes (see Hoffman \& Musil, 2009). Many cities also used the advantage of tourism growth to revitalize former industrial parts. "Some cities managed to make a smooth transition from industrial wasteland to tourist mecca." (Fainstein \& Judd, 1999, p. 12).

This development of urban tourism has spurred an interest among researchers. Since the end of 1980's, more comprehensive publications about urban tourism have appeared, mostly focusing on Anglo-Saxon cities (cf. Law, 1993; Ashworth \& Tunbridge, 1990; Page, 1995; Judd \& Fainstein, 1999; Hoffman, Fainstein, \& Judd, 2003; Haylar, Griffin, \& Edwards, 2008; or Maitland \& Ritchie, 2010). In continental Europe, however, the urban tourism research has been still neglected to a certain degree. Most of the case studies and contributions concerned only certain parts of this phenomenon have been pub- 
lished without more in-depth research on the urban tourism being conducted (e.g. Berg, Borg, \& Meer, 1995; Borg, Costa, \& Gotti, 1996; Pearce, 1998; Ark \& Richards, 2006; Mazanec \& Wöber, 2010; Popp, 2011; Thurnell-Read, 2012). A similar gap in the urban tourism research is visible in Central Europe where urban tourism literature is limited in scope (e.g. Cooper \& Morpeth, 1998; Simpson, 1999; Clift \& Carter, 2000). The same holds true for the tourism research on Prague (Hoffman \& Musil, 2009; Čermáková, 2012; Dumbrovská, 2013; Šauer \& Holešinská, in press).

\section{Definition of urban tourism}

Cities, especially capital cities, play a significant role in tourism. They are multifunctional entities, which serve both as tourist destinations, gateways, hubs, and as important tourism sources (Pearce, 2001). "Cities offer a beguiling array of possibilities for the tourist from theaters to museums, from parks to palaces. They are an ideal locus for the provision of entertainment and dinning, and the presentation of culture" (Metro-Roland, 2011, p. 5). According to Ashworth (2009, p. 209), "only cities have the critical mass of such resources to attract and satisfy tourism demands."

Urban tourism, as its name suggests, represents tourism activities embodied in urban area. It is the city and its environment which distinguishes urban tourism from other types of tourism. According to Pearce (2001, p. 927), "urban areas are distinctive and complex places. Four accepted qualities of cities are high physical densities of structures, people, and functions; social and cultural heterogeneity; an economic multifunctionalism; and a physical centrality within regional and interurban networks." Following this definition the authors can deduce basic aspects of tourism in cities: (1) Cities concentrate a multitude of tourist attractions in a relatively small area; (2) These attractions are diverse and thus attract different types of tourists; (3) Most of tourist facilities have not been primarily intended for tourists and this leads to a mutual interaction between different types of urban users (tourist, residents, or workers); (4) Different types of economic activities take place in cities and tourism is only one among many. According to Ashworth and Page (2011, p. 1), "It is the cities with a large and varied economic base that gain the most from tourism but are the least dependent upon it"; (5) Cities are significant regional centers and as such they dispose of well-developed infrastructure, not only regarding transportation, but also regarding services (e.g. restaurants, cafes, bars, or shops) and accommodation (hotels, pensions, or hostels.).

Edwards, Griffin, and Hayllar (2008, p. 1038) define urban tourism as "one among many social and economic forces in the urban environment. It encompasses an industry that manages and markets a variety of products and experiences to people who have a wide range of motivation, preferences and cultural perspectives and are involved in a dialectic engagement with the host community". A large amount of visitors come to cities for business purposes (Ashworth \& Page, 2011), such as conferences and meetings. Tourists represent another vast category of visitors who come to cities for leisure activities. This is called a city break. 
The city breaks are relatively new and rapidly growing phenomenon in tourism. Generally, one can define five basic characteristics that distinguish the city breaks from other type of city tourism - duration, distance, date flexibility, discretionary nature, and destination travel party (Dunn, Flanagan, \& Buckley, 2010). The city break can be therefore defined as a short leisure trip to one city (Trew \& Cockerell, 2002) that is near to the tourist's country of residence. The city breaks are not tied to a specific season and are often taken as "secondary trips, complementing the traditional summer-long annual holidays which are coastal-based" (Page, 2002, p. 121). These trips are usually easy to plan and tourists often choose their city destination at the "last minute" (from day to day). Cities are not suitable as family destinations; therefore they are mostly visited by couples and groups of friends (Dunn, Flanagan, \& Buckley, 2010).

The expansion of urban tourism and especially the city breaks have been empowered by the development in transport and information technologies (Dunn, Flanagan, \& Buckley, 2011). The expansion of low-cost airlines has brought a relatively fast and cheap connection between city destinations and facilitated short trips to cities. On the other hand, the expansion of the Internet connection and booking systems has facilitated searching for information about destinations and potential visitors can therefore decide about their trip in a relatively short time. However, the innovations in transport and information technologies have also some negative consequences (see e.g. Castillo-Manzano, López-Valpuesta, \& González-Laxe, 2011). It is primarily a growing popularity of "stag and hen tourism", when groups of young tourists travel to cities for entertainment such as visiting bars, discos, and casinos (see e.g. Hall, Smith, \& Marciszewska, 2006; Thurnell-Read, 2012). Other negative impacts are connected with an overall increase of tourists in cities, which causes congestion, tourist inflation, and turistification in that parts of cities where tourist concentration is the highest (see Simpson, 1999). This concentration in a particular part of the city can cause an increasing irritation among the host community (Doxey, 1975) and leads to what is called "dual local society" (Pásková, 2012). These issues cause the effect of tourism trap when "unregulated tourism has devaluated its own equity by its economic activities and thus has undermined its own preconditions for economical, ecological, and socially sustainable development" (Pásková \& Zelenka, 2002, p. 72).

\section{Urban tourism localization}

Urban tourism is not equally distributed across the city. There is a strong concentration in certain areas, for which notions like "tourist enclaves" (Judd, 2003), "tourism business districts" (Getz, 1993), "tourist districts" (Pearce, 2001) or "urban tourism precincts" (Hayllay, Griffin, \& Edwards, 2008) have been used in literature. According to Hayllar and Griffin (2005, p. 517), "a tourism precinct represents a distinctive geographic area within a larger urban area, characterized by a concentration of tourist-related land uses, activities and visitation, with fairly definable boundaries". These areas are unique for their concentration of tourist facilities such as tourist sites, museums, restaurants, hotels, or souvenir shops which attract tourists. 
These tourism precincts can be focused on different attractions and there can be more than one precinct in a city. Pearce (2001) distinguishes six types of tourism precincts: historic, ethnic, sacred, redevelopment, entertainment, and functional. Griffin, Hayllar, and Edwards (2008) criticize this classification as superficial and argue instead that a classification of urban tourism precincts should "be based on functional considerations. For example, precincts could be classified as: meeting place, place of orientation, comfort zones, places of respite or refuge, play spaces, zones of authenticity..." More of these functions may evolve within a single precinct. (Griffin, Hayllar, \& Edwards, 2008, p. 54). The first classification (Pearce, 2001) is more general and shows the basic types of precincts based on evolution aspects. The second one (Griffin, Haylar, \& Edwards, 2008) goes more in depth and it is more useful for planning and managing the precincts.

\section{Methods}

The aim of this article is to shed a light on tourism in Prague and its role among similar cities. Vienna and Budapest have been selected for the comparative analysis as the cities with similar volume of tourism, historical development, city size, the number of inhabitants and similar culture. The urban tourism development is examined in the period of 2003 to 2011. The year of 2003 was selected as an initial year of the analysis because there was no significant tourism event in that year, which would distort the representativeness of data (e.g. floods in Prague in 2002 or terrorist attacks in the United States in 2001). Also, in the period of 2003 to 2011 one can benefit from the uninterrupted data series.

The analysis is based on secondary data from three types of statistical databases: Eurostat, TourMIS, and regional databases of statistical offices of Czechia (Český statistický úřad [ČSÚ]), Austria (Magistrat der Stadt Wien) and Budapest (Hungarian Central Statistical Office [HCSO]). From the Eurostat database, general data about cities such as the number of inhabitants, or the total area of cities have been used. The data from TourMIS reference to the number of tourists, their overnight stays, and the number of beds in Prague, Vienna and Budapest. The national statistical offices were used to fill the gaps in data series and to gain the data for volume of tourism in municipal districts of the represented cities.

The collected data were processed and analyzed in the forms of table, graph, and map outputs. In the first part of the article, the development of tourism in Prague in comparison with Vienna and Budapest is examined. For the analysis of tourism development the index of growth in the period of 2003 to 2011 has been used (the year 2003 represents $100 \%)$. As the second indicator of growth the annual bed-occupancy has been used, which signifies the percentage of beds in collective accommodation establishments, actually used by guests.

In the second part of the paper the intensity of tourism in the monitored cities is investigated. The tourism intensity was analyzed on the basis of tourism intensity indicators, which measure the volume of tourism (numbers of arrivals, number of overnight 
stays, and number of beds in collective accommodation establishments) in proportion to the number of city inhabitants or to the overall city area. These indicators are as follows: tourist intensity rate (TIR), tourist penetration rate (TPR), tourist density rate (TDR), Defert function (DF), and impact of tourism activities on the locality (TL).

The third part of our analysis compares tourism intensity in municipal districts of the monitored cities and thus focuses on the localization of tourism in cities. The tourist intensity indicators (TPR and DF) have been used for this purpose and the results has been presented in the form of cartograms of the monitored cities. The values of TPR and DF were divided into five categories by the natural breaks and then the categories in each cartogram were adjusted for the comparison (to be uniformed in each cartogram of the same indicator).

In the fourth part the seasonality of tourism in Prague with Vienna and Budapest and its development between 2003 and 2011 has been compared. There has been used monthly numbers of overnight stays in public accommodation establishments. The tourism intensity indicators refer to the rate of burden of tourism on these destinations. The authors examine a burden created by both tourists and tourism infrastructure on the destination.

\section{Role of Prague in urban tourism}

Urban tourism is a fast worldwide growing type of tourism. According to Euromonitor (2012), international tourist arrivals in cities increased by $7 \%$ between 2010 and 2011, while the number of overall international arrivals increased by only $4.6 \%$ in the same period (UNWTO, 2012). The most visited cities were Hong Kong, Singapore and London in 2011; Prague, Vienna and Budapest were placed in the third ten of the ranking (Euromonitor, 2012).

Significant amount of tourists visit cities for business purposes (see above). According to the International Congress and Convention Association (ICCA, 2012), Europe hosted the greatest number of meetings (59\%). The worldwide most popular destination measured in number of business meetings in 2011 was Vienna (181 meetings) followed by Paris, Barcelona, and Berlin, while Budapest and Prague ranked eleventh and fourteenth respectively (ICCA, 2012).

The Travel and Leisure magazine and the travel server Trip Advisor made a survey to explore the most favorite destinations among tourists in 2013. The Travel and Leisure magazine (2013) estimated the top three city destinations in 2013 to be Bangkok, Istanbul and Florence. The Trip Advisor (2013) ranked as the top three destinations Paris, New York and London. Among the European cities, Prague ranked seventh in both surveys, while Vienna was on the eights place by the Travel and Leisure magazine (2013) and thirteenth by the Trip Advisor (2013) and Budapest ranked seventeenth by Trip Advisor (2013).

Urban tourism trends and rankings indicate that Prague has taken a significant place among city tourism destinations, comparable to Vienna and Budapest. 


\section{Prague, Vienna and Budapest}

Prague, Vienna and Budapest are culturally, historically, and architecturally similar cities. They are capitals of countries that are members of the European Union and the Schengen Area. They all were members of a common empire for a considerable time and each of them was the seat of the king. For these reasons they have similar architectural environment and historical background. Metro-Roland (2011, p. 3) states according to Puczkó, Rátz, and Smith (2007) that "the Americans especially find it difficult to distinguish between Prague, Vienna, and Budapest".

The surveyed cities are also similar in size of land area and population with the population density being the highest in Vienna and lowest in Prague. In general, the differences between these cities are insignificant and therefore suitable for our comparison (see Figure 1). The number of tourist arrivals and the number of overnight stays are very similar in the case of Prague and Vienna, the volume of tourism in Budapest is at half (see Figure 1). Larger differences among the cities can be identified when the data are relativized. In the case of the number of arrivals per 100 inhabitants (TIR) Prague reached twice higher number than Vienna and almost three times higher number than Budapest. One can observe a similar situation in the case of the number of beds per $\mathrm{km}^{2}$ (TL). TL was the highest in Prague followed by Vienna and Budapest in 2011 (see Figure 1). These tourism intensity indicators (TIR and TL) demonstrate that Prague has the biggest volume of tourism among the surveyed cities.

Figure 1 Selected indicators for Prague, Vienna and Budapest in 2011

\begin{tabular}{|c|c|c|c|c|c|c|c|c|}
\hline & 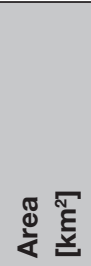 & 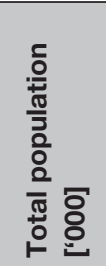 & 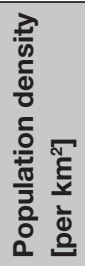 & 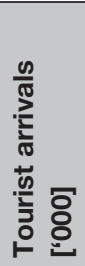 & 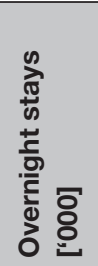 & 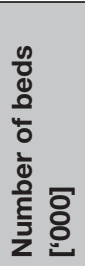 & $\stackrel{\complement}{F}$ & $\vec{F}$ \\
\hline Budapest & 525.2 & 1733.7 & 3302 & 2813 & 6599 & 42.8 & 162.3 & 81.5 \\
\hline Prague & 496.1 & 1241.7 & 2503 & 5132 & 12948 & 78.0 & 413.3 & 157.2 \\
\hline Vienna & 414.9 & 1714.1 & 4131 & 5227 & 11405 & 57.4 & 299.4 & 138.4 \\
\hline
\end{tabular}

Source: TourMIS (2013), ČSÚ (2013), Magistrat der Stadt Wien (2013), HCSO (2013), Dumbrovská (2013)

\section{Tourism development in Prague, Vienna and Budapest}

Tourism in Prague, Vienna, and Budapest has a relatively long tradition, because these are old and historically significant cities. Nevertheless, two World Wars and the subsequent bipolar division of the world interrupted the development of tourism in Central 
Europe. The fall of the Iron Curtain was a significant milestone for tourism in Central Europe. Prague and Budapest opened up to western tourist markets, which subsequently lead to an increased tourist urban competition in Central Europe. Other significant events, which positively affected the tourist development in these cities, were the accession to the European Union and the Schengen Area.

The volume of tourism in the selected cities has grown since 2003, especially when one looks at the number of tourist arrivals to collective accommodation establishments. Since 2003, the numbers of tourists has increased by almost $70 \%$ in Prague, by approximately $55 \%$ in Vienna and by more than $40 \%$ in Budapest (see Figure 2). A similar increase can been seen in the number of tourist overnight stays in collective accommodation establishments although it has grown slower than the number of tourist arrivals during the observed period, which indicates a long-term trend of shortening of the length of tourist stays in these cities. These observations confirm the basic indicators of urban tourism and the city breaks in particular, which shows that tourists stay in these cities for a short time only (see above). The number of beds in collective accommodation establishments has grown slower than the number of tourists measured both in arrivals and overnight stays. A similarly slow increase or even stagnation can be seen in the number of beds and the number of hotels and boarding houses (see Figure 2). The number of beds and hotels and boarding houses has increase the least in Prague, while Vienna displays one-third increase in the number of beds. From this analysis it is evident that there is not a balance between the increase of tourist overnight stays and the capacity to accommodate these tourists measured as a number of beds, which raises a question about the sustainable development of tourist accommodation establishments and a question concerning the annual bed-occupancy.

Figure 2 The growth of tourism in Prague, Vienna and Budapest in 2003-2011 (2003=100)

\begin{tabular}{|l|c|c|c|c|}
\hline & Arrivals & Overnight stays & Number of beds & $\begin{array}{c}\text { Hotels and Boarding } \\
\text { houses }\end{array}$ \\
\hline Budapest & 143.1 & 128.0 & 116.7 & 117.7 \\
\hline Prague & 169.7 & 156.9 & 111.4 & 111.9 \\
\hline Vienna & 156.0 & 143.7 & 133.3 & 113.9 \\
\hline
\end{tabular}

Source: TourMIS (2013), ČSÚ (2013), Magistrat der Stadt Wien (2013), HCSO (2013)

Annual bed-occupancy has been in Prague and Budapest relatively low; since 2003, it has not surpassed $45 \%$, with the exception of 2005. By contrast, Vienna has had a longterm higher occupancy ratio with the annual bed-occupancy falling below $55 \%$ only in 2009 (see Figure 3). When one compares Figure 1 with Figure 2, he can see a positive trend in the development of beds in Prague and Budapest. Dumbrovská (2013) warned in her diploma thesis that the capacity of beds in collective accommodation establishments in Prague might be overestimated. The current trend of a significantly slower increase of bed capacity than the increase of overnight stays is a positive tourism trend in 
Prague and Budapest. This trend could be also seen in Figure 3, which shows an increase in annual bed-occupancy since 2009 in all three observed cities.

Figure 3 Annual bed-occupancy in collective accommodation establishments in Prague, Vienna and Budapest in 2003-2011 [\%]

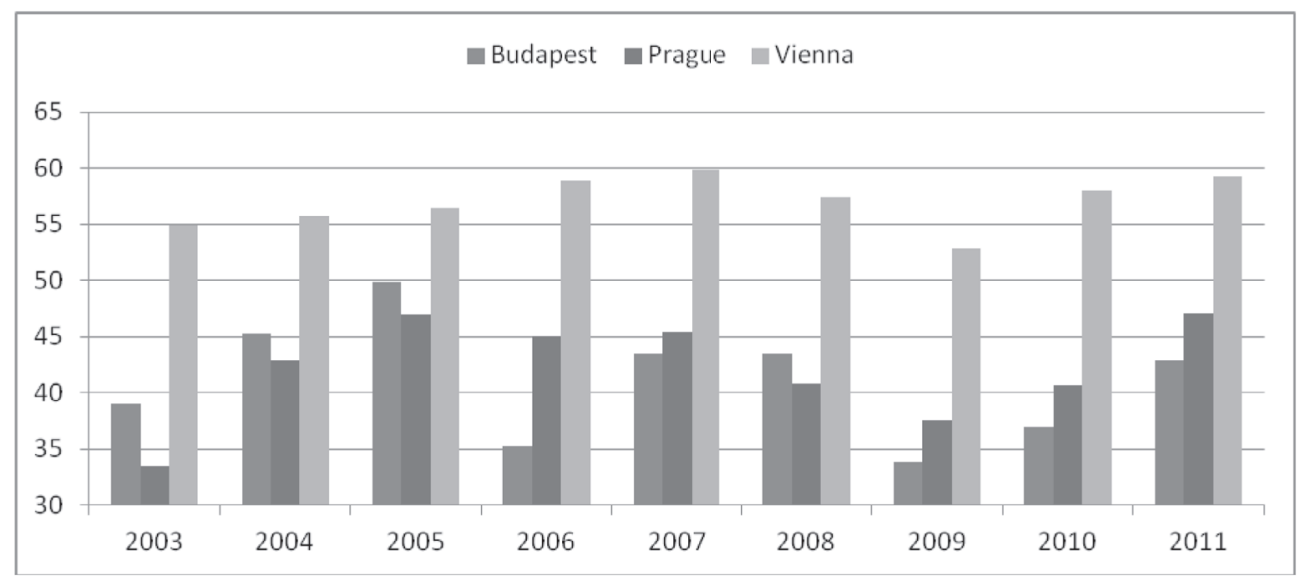

Source: TourMIS (2013)

\section{Tourism intensity in Prague, Vienna and Budapest}

Although Prague, Vienna and Budapest are cities with a similar area and number of inhabitants, they are not equal and therefore it is necessary to work with relativized data for their comparison. In this and the following parts the authors use the tourist intensity indicators. Generally, these indicators relate the classic tourist indicators (such as overnight stays, number of beds, or tourist arrivals) to the city area or the number of inhabitants (for more see the part on methods above).

In the first part of this article the authors suggested that the tourism intensity in Prague should be higher than in the case of Vienna and Budapest. The first indicator, they use, is the tourist penetration rate (TPR), which shows how many tourists are in the destination per day per 100 inhabitants in average. Prague has had the highest TPR of the monitored cities in the long term. The TPR in Prague has increased by almost one tourist per 100 residents since 2003 (see Figure 4). The only exception is 2009 when there was a decline in the number of visitors in all three cities. This decrease was caused by the global economic crisis, which significantly affected the disposable income of the population and subsequently the overall decline in tourism in the world. On the other hand, the recovery was fast in all three cities (see Figure 4 and 5). For instance, in 2011 there were three tourists per 100 inhabitants on daily average in Prague, two tourists in Vienna and one tourist in Budapest. 
Figure 4 Tourist penetration rate in Prague, Vienna and Budapest in 2003-2011 [per 100 inhabitants]

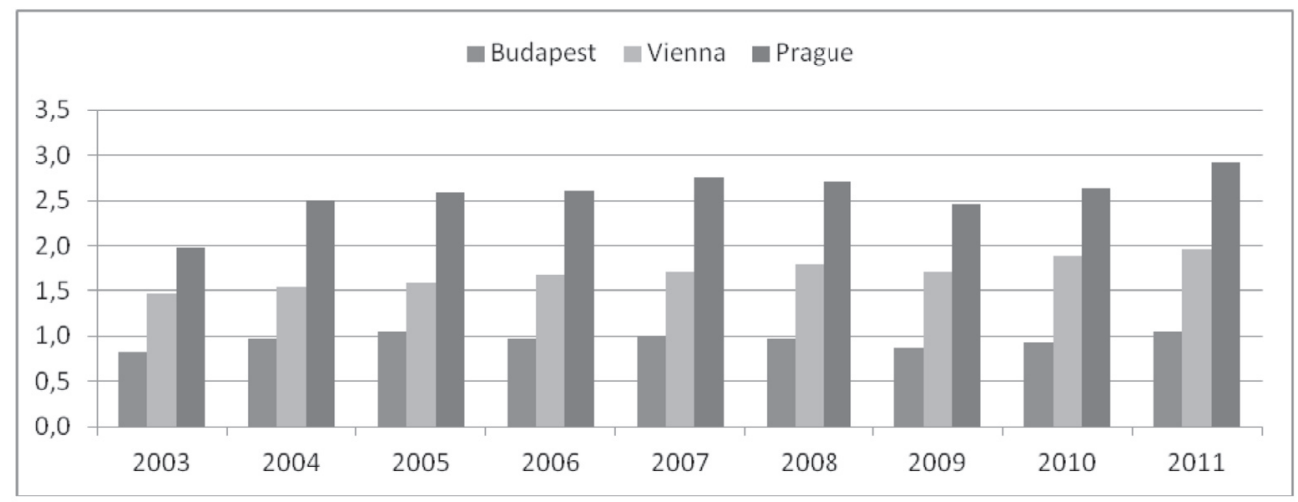

Source: Eurostat (2013), TouMIS (2013)

The tourist density rate (TDR) indicates how many tourists are approximately in the destination per day per $1 \mathrm{~km}^{2}$. This indicator shows a less significant position of Prague in comparison with the two other cities than in the case of TPR. Although the TDR has long been consistently higher in Vienna than in Prague and Budapest, the difference between Prague and Vienna is negligible (see Figure 5). In 2011, there were 81 tourists on average per day per $1 \mathrm{~km}^{2}$ in Vienna, 73 tourists per day per $1 \mathrm{~km}^{2}$ in Prague, and only 34 tourists per day per $1 \mathrm{~km}^{2}$ in Budapest. Tourists are usually concentrated in certain areas of the city (for more see above) and therefore the TPR and TDR results must be analyzed with this factor in mind. The overloads of urban tourism precincts are higher than in other parts of the cities. However, as the authors have pointed out above, the boundaries of the precincts could not be clearly delimitated and therefore they use administrative boundaries of the whole city in this research. In the following paragraphs, they examine the burden created by tourism infrastructures on the cities and the relative number of beds in each of the destinations.

The tourist infrastructure burdens of the city can be measured by two indicators. The first one is the Defert function (DF), which shows the number of beds per 100 inhabitants. The Defert function has reached lower values in the examined cities than in the case of mountain destinations and coastal resorts. Nevertheless, these results are significant because the indicator allows a comparison among these cities. Prague has consistently reached twice the values of DF of Vienna and Budapest. In Prague there were 6 beds per 100 residents in 2011, while Vienna disposed only of 3 beds per 100 inhabitants and Budapest by 2.5 beds (see Figure 6). If one perceives the DF indicator as demonstrating the potential number of tourists in the city, then the comparison between the results shown in Figure 6 and the results shown in Figure 3 reveals that the capacity of accommodation facilities in Prague is overloaded. This trend is not sustainable in the future. 
Figure 5 Tourist density rate in Prague, Vienna and Budapest in 2003-2011 [per km²]

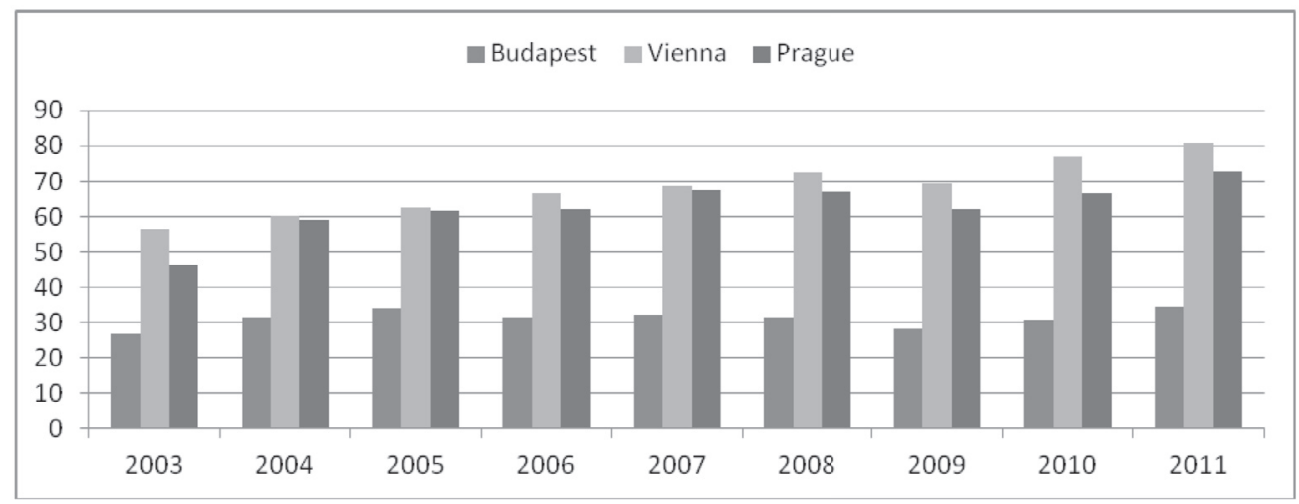

Source: Eurostat (2013), TourMIS (2013)

Figure 6 Defert function in Prague, Vienna and Budapest in 2003-2011 [per 100 inhabitants]

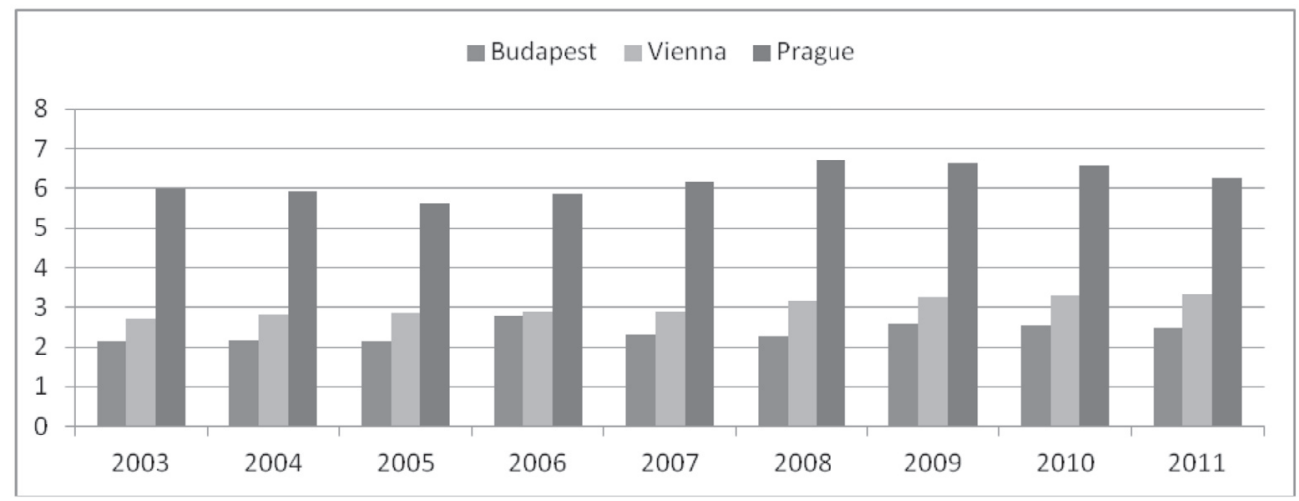

Source: Eurostat (2013), TourMIS (2013)

The second indicator, the impact of tourism activities on the locality (TL), shows the density of tourist accommodation facilities (measured in beds) in the destination by measuring the number of beds per $1 \mathrm{~km}^{2}$. Similarly in the case of the DF, Prague has also reached the highest value of TL. In 2011, there were 160 beds per $\mathrm{km}^{2}$, while in Vienna there were some 140 beds per $\mathrm{km}^{2}$, and in Budapest only 81 beds per $\mathrm{km}^{2}$ (see Figure 7).

The indicators referring to the intensity of tourism (TPR, TDR, DF, and TL) show a high load of tourism in Prague and its significant impact on the city. The tourist intensity in Prague is according to almost all of the indicators higher than in Vienna and Budapest. However, the development of tourism in Prague is unbalanced when one relates 
the number of beds to the number of tourists. The unbalanced development is also noticeable in connection with effects of economic crises in 2008 and 2009. While the number of beds in Vienna slowed down its growth in this period, the number of beds in Prague has declined since 2008.

Figure 7 Impact of tourism activities on the locality in Prague, Vienna and Budapest in 2003-2011 [per km²]

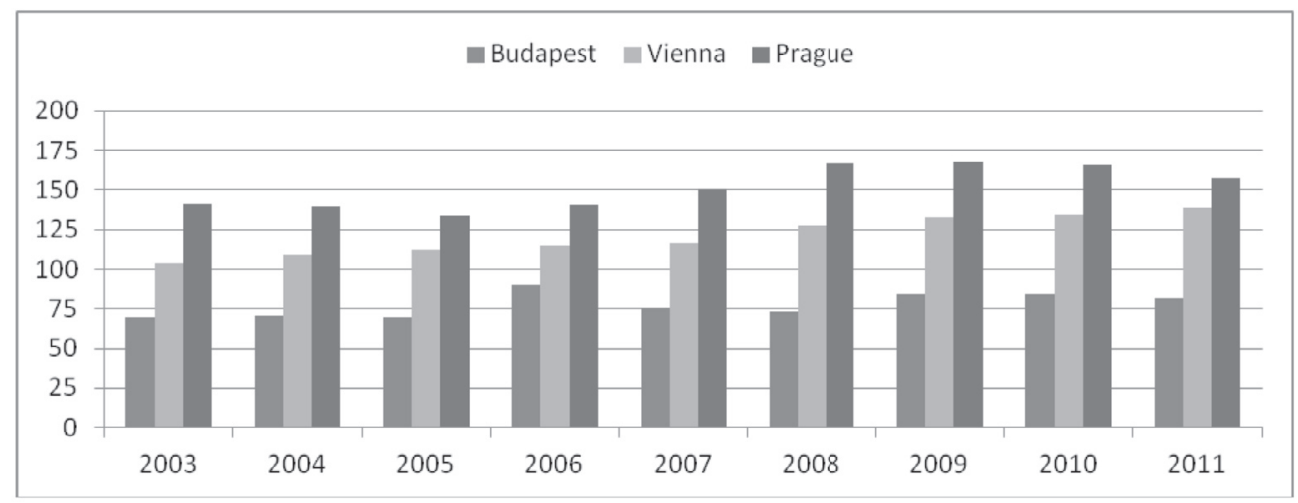

Source: Eurostat (2013), TourMIS (2013)

\section{Tourism intensity in municipal districts of Prague, Vienna and Budapest}

The urban tourism, as the authors have pointed out above, tends to concentrate in certain parts of the cities, i.e. in the urban tourism precincts. In historical cities like Prague, Vienna, and Budapest, the urban tourism precincts are embodied in their historical parts, which are characterized by the highest concentration of tourists. In this section the authors analyze the distribution of tourists and tourism infrastructure in Prague in comparison with Vienna and Budapest.

The tourist penetration rate has reached the highest values in historical districts of the selected cities. In Prague and Vienna, there has been the highest TPR in the first municipal districts and in Budapest in the fifth municipal district; all of them being the oldest parts of the city. In Figure 8, a strong concentration of tourists into those parts of the city that have been designated the Areas of the World Heritage Property by the UNESCO can be observed, while the values of TPR decline towards the edges of the city. In Prague one can see a higher tourist burden also in the surrounding municipal districts of the city center, while in Budapest a declining trend of TPR towards the edges of the city is clearly recognizable (see Figure 8). Prague's first municipal district has had the highest value of TPR among the selected cities; 41 tourists per 100 residents per day were accommodated in 2011 in Prague on average. In the first municipal district of 


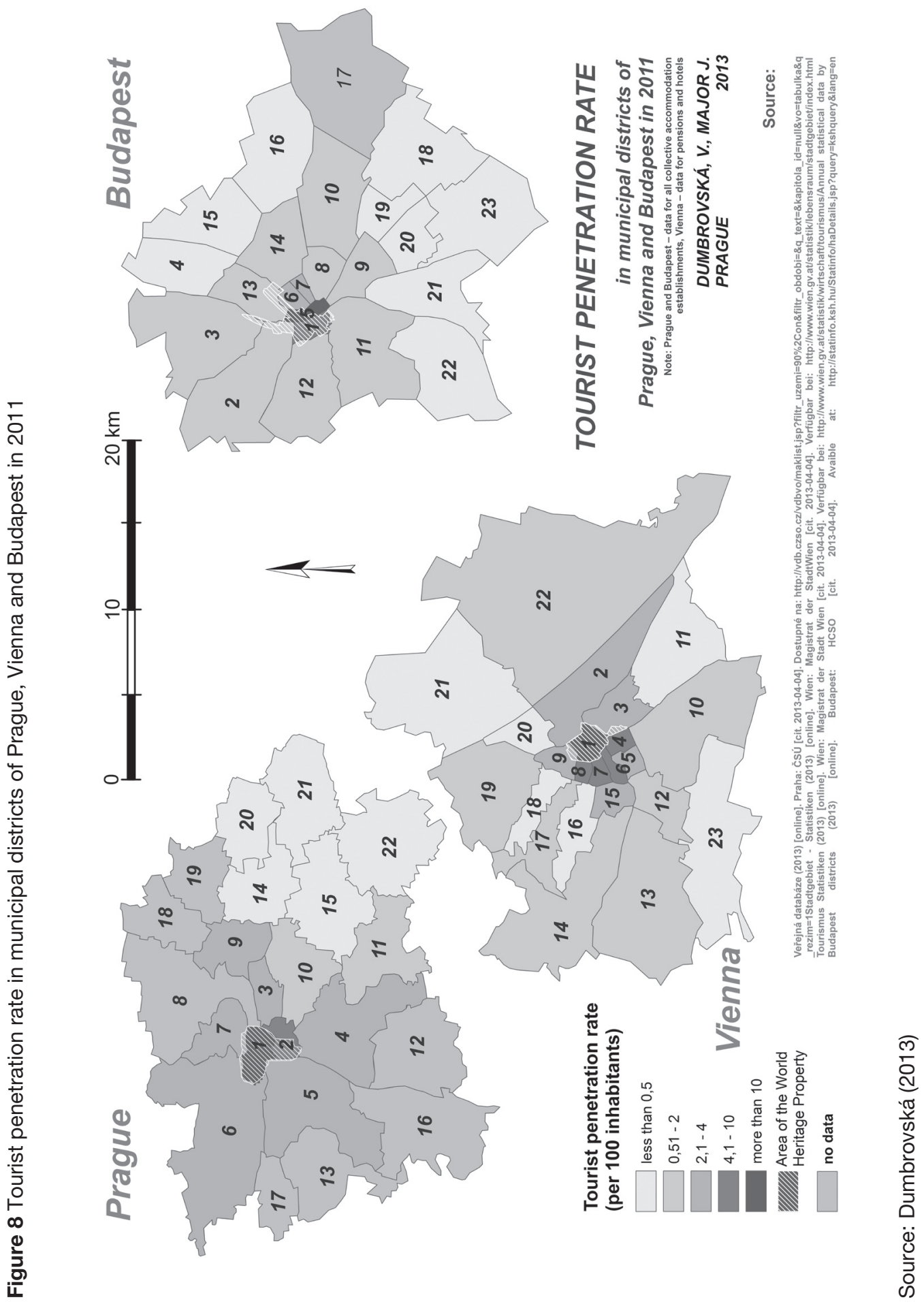




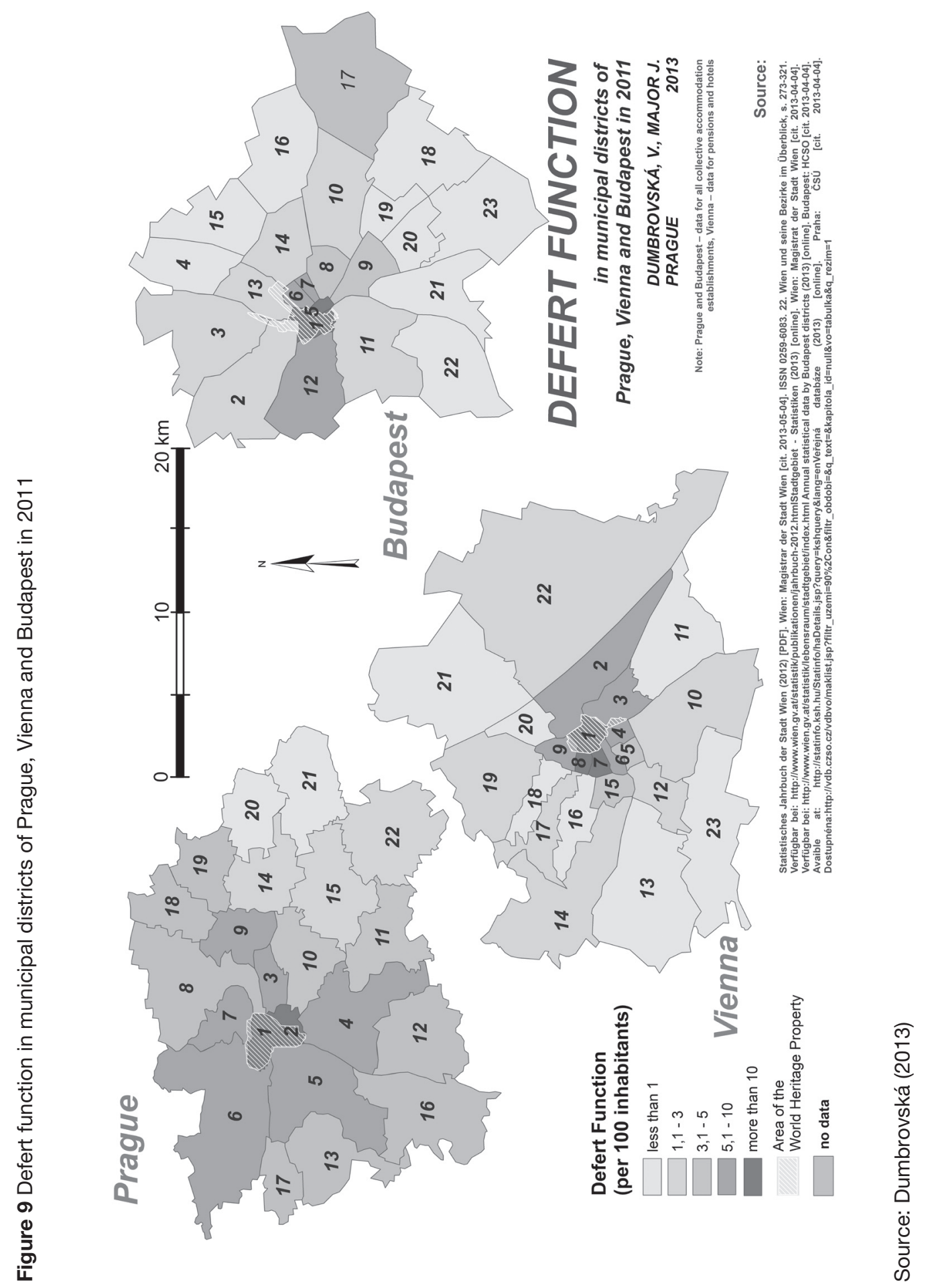


Vienna, there were 33 tourists per day per 100 inhabitants in 2011 on average, and in Budapest's fifth district, the TPR was only 15 tourists per 100 residents per day in 2011 on average (Dumbrovská, 2013). These findings, summarized in Figure 8, prove the premise presented above that Prague is overloaded with tourists, especially in the historical parts of the city. These findings deal only with the accommodated tourists in the analyzed cities. In fact, the overload of the city center is much higher. First, the city center is visited by other tourists who visit the city but who are accommodated beyond its historical parts, and by tourists who do not stay overnight. And second, people, who live in the city center, but are not counted in official statistics (tenants without permanent residence), and people who work in the city center, add to this overload.

The distribution of beds capacity is similar as the distribution of tourists in the analyzed cities. The highest values are observed in the city centers. The Defert function indicates the highest numbers of beds in the first municipal districts of Prague and Vienna and in the fifth municipal district of Budapest. As in the case of TPR, the values of DF are declining towards the edges of the cities. However, while the concentration of beds in the city centers of Vienna and Budapest is high, the bed capacity in Prague is more dispersed between the city center and the adjacent districts (see Figure 9). The highest values are observed in the Prague's first municipal district with 74 beds per 100 residents in 2011. In the Viennese first municipal district, the DF was 55 beds per 100 inhabitants; and in Budapest's fifth district, the DF was 55 beds per 100 residents in 2011 (Dumbrovská, 2013). In the case of Prague, the number of beds per 100 inhabitants is higher in the districts situated on the line between the city center and Václav Havel Airport located in the western part of the city (see Figure 9). If one compares Figures 8 and 9, he may identify similar dispersion of tourists and beds in Vienna and Budapest. However, in Prague the DF shows higher numbers even in the municipal districts further from the city center (districts 14, 15, and 22; see Figure 9). Based on the findings, one can conclude that the supply of accommodation capacity in Prague is not in balance with the demand.

\section{Seasonality of tourism in Vienna, Prague, and Budapest}

The seasonality is one of the basic characteristics of the city tourism (see above). The tourist season is usually longer in cities than in other types of destinations (e.g. coastal and ski resorts). In this part of the article, the authors attempt to explore the issue of seasonality in Prague in comparison with Vienna and Budapest and to identify tourist strong and weak months and the development between 2003 and 2011.

In contrast to other types of destinations, tourists visit cities like Prague, Vienna, and Budapest all year long. Despite some differences in proportion of tourist overnight stays between summer and winter months, the number of tourist overnight stays in any single months did not fall below $4 \%$ of the annual overnights in the observed period (see Figure 10). One can identify a higher concentration of tourists in spring and summer months. In 2011 in Prague and Vienna, the peak tourist season was the summer months, 
followed by the spring months, while in Budapest the peak tourist season was in spring (May) with a second peak in summer (August) (see Figure 10). The weakest months regarding the numbers of tourist overnight stays were February, January and November in all the cities. The most equal distribution of tourist overnights could be found in Vienna in 2011 where in any months the numbers did not fall under $4.6 \%$, but also did not exceed $11 \%$. In Budapest, on the other hand, the difference between moths in overnight stays was significant - from $4.06 \%$ in February to $13.5 \%$ in May (see Figure 10). The data for 2011 show that Prague compared to Vienna and Budapest had a strong overall position of the annual overnight stays in the month of April. This could be thanks to good marketing activities associated with Easter holidays in Prague. On the other hand, the proportion of the annual overnight stays in Vienna in December was higher than in Prague, which indicates better promotion activities for the Christmas holidays.

Figure 10 The distribution of tourist overnight stays in collective accommodation establishments in Prague, Vienna and Budapest in 2011 [\%]

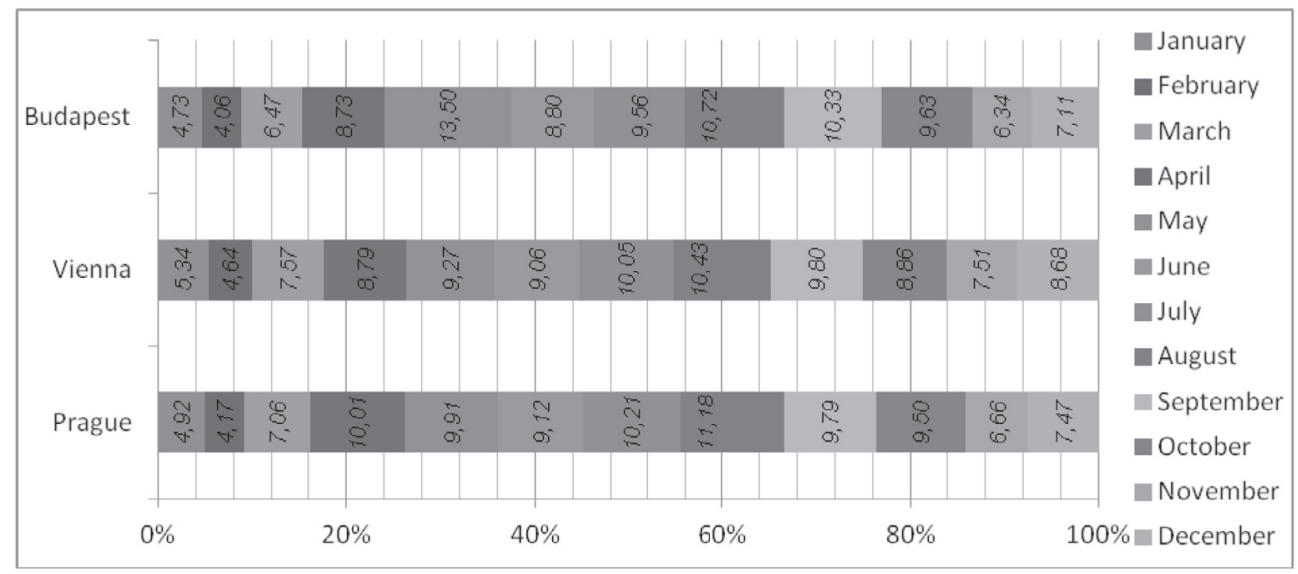

Source: TourMIS (2013), Čsú (2013)

The growth of overnight stays by months indicates a positive trend of the development of tourism in the selected cities. The number of overnight stays in the weaker months has increased faster than in traditionally tourist stronger months since 2003 (see Figure 11). Thus one can observe a gradual convergence of the number of tourist overnight stays in different months of the year. Although there has been a significant increase of tourist overnight stays in the month of January in all the cities, in the proportion to other months it remained considerably low (see Figure 10). On the other hand, the increase of overnight stays in the month of November has been the lowest one in the observed period in Prague and Budapest (see Figure 11). In general, November and February are the least favorite months in urban tourism. In this part of the year, the weather in Central Europe is often unfavorable and moreover, there is a significant tourist-marketing 
gap for these months. The month of November then suffers from being between two tourist strong seasons - the summer months and the Christmas holidays; similarly, being between the Christmas and Easter holidays causes the low numbers for the month of February. This poses a challenge for the city tourism marketing to evolve effective and well promotable tourist products for these months.

Figure 11 Growth of overnight stays in collective accommodation establishments by months in Prague, Vienna, and Budapest in 2003-2011 (2003=100)

\begin{tabular}{|l|c|c|c|c|c|c|c|c|c|c|c|c|}
\hline & $\mathbf{1}$ & $\mathbf{2}$ & $\mathbf{3}$ & $\mathbf{4}$ & $\mathbf{5}$ & $\mathbf{6}$ & $\mathbf{7}$ & $\mathbf{8}$ & $\mathbf{9}$ & $\mathbf{1 0}$ & $\mathbf{1 1}$ & $\mathbf{1 2}$ \\
\hline Budapest & 139 & 126 & 124 & 128 & 177 & 131 & 117 & 114 & 117 & 116 & 115 & 143 \\
\hline Prague & 197 & 152 & 149 & 173 & 161 & 173 & 144 & 140 & 140 & 152 & 134 & 163 \\
\hline Vienna & 162 & 142 & 156 & 156 & 140 & 149 & 156 & 132 & 135 & 131 & 144 & 143 \\
\hline
\end{tabular}

Source: TourMIS (2013), Čsú (2013)

\section{Discussion}

The aim of this article is to examine the situation of tourism in Prague in comparison with Vienna and Budapest. The authors have used quantitative indicators to explore the development of tourism and tourism intensity in Prague, Vienna and Budapest, the geographical distribution of tourism in the city area and its distribution over the year (tourism seasonality). The comparative analysis of the selected cities is based on the index of growth and tourist intensity indicators. The qualitative analysis was not used because of the lack of comparable data.

Despite the fact that the authors have achieved the aim of their analysis, they had to deal with several distinct problems. The first one concerned the data compatibility in different land area (see above). The second issue was the selection of the geographical area for the research. In particular, whether to analyze the selected city in their entire administrative boundaries or whether to focus solely on the historical parts of these cities, which are the targets of most of the tourists. They have opted for the administrative boundaries of the whole city. The reason is that the urban tourism precincts are difficult to determine with sufficient accuracy (see the part on Urban tourism localization above). Thus they have compared three cities and their results are therefore primarily relative, the choice of the geographical area does not affect the results. It poses a challenge for further research to define the boundaries of urban tourism precincts and the number of tourist arrivals or overnight stays relativized to this area. The outcomes may detect significantly higher tourist intensity than they did. A similar situation can be identified also in the case of the city population. In this analysis the authors use the population of the whole city, but they could have used only the population of the urban tourism precinct if they had been able to localize the data to the precincts only. The problem with accurate data on the urban tourism precincts is complicated also by the fact that there 
are not only tourists and residents in these areas, but also workers, students, day trippers, and other daily users of the city. For instance, the official statistics on the number of residents are often underestimated. Therefore, in some respect, working with the data on population of the whole city may bring more accurate results.

Here, they have touched upon another problem, the one of the accuracy of the data from the official statistical databases. The statistical data for tourism are in all three cities (and countries) collected by collective accommodation establishments in the form of questionnaires from their guests. The data for the tourists accommodated in small establishments, private houses or at friends' and relatives' are therefore not reflected in the official statistical databases. The analyses based on these data are therefore inaccurate as they work with the underestimated numbers. However, as it has been mentioned above, this problem does not affect the analysis as the authors focus on relative numbers (comparing tourism in Prague with tourism in Vienna and Budapest), not on absolute numbers.

The findings also indicate areas of further research; in particular more research is needed in order to examine in detail the overload of tourism in Prague in comparison with Vienna and Budapest with regard to the relationship between tourists and residents, the development of prices in the city center, the change of retail-store types in the city center, and the development of regulatory policies aiming at the sustainable development of the city.

\section{Conclusion}

Urban tourism is a rapidly growing type of tourism. City destinations have experienced an unprecedented development, especially during the last decade. Prague, Vienna and Budapest are among these prominent city destinations where the number of tourists has increased by more than $40 \%$ in the period between 2003 and 2011.

Prague, Vienna, and Budapest are similar cities in culture, architecture, city area, and city population. The volume of tourism is also similar, especially in the case of Prague and Vienna. The volume of tourism in Budapest is approximately at half. The highest growth of tourism has been recorded in Prague, the number of tourist arrivals to collective accommodation establishments increased by $70 \%$ between 2003 and 2011. However, the development of tourism in Prague is not balanced and there has been a rapid increase in the tourist intensity. Prague and Budapest has reached a very low level of bed occupancy in accommodation establishments. It has been around $40 \%$ since 2003. Despite that, one can see a positive trend that shall affect the capacity soon as the number of beds has increased slower than the number of overnight stays in accommodation establishments in Prague and Budapest between 2003 and 2011.

Prague has achieved a significant position regarding the tourist intensity among the surveyed cities. In almost all the tourist intensity indicators Prague has reached the highest numbers. The number of beds per inhabitants has been even twice higher in Prague than the number in other cities. This difference between the surveyed cities becomes obvious when one looks at the municipal districts of these cities. 
Tourism in cities is concentrated in certain parts, the so-called urban tourism precincts. In Prague, Vienna, and Budapest, the authors have identified a strong concentration of tourism in the historical parts of the cities, which are included in the UNESCO's List of world cultural heritage sites. The intensity of tourism is highest in these parts of the cities and the intensity of tourism rapidly decreases towards the edge of the cities. Prague's historical center achieved the highest values in both monitored indicators (TPR and DF) among the analyzed cities and the higher intensity of tourism has been also recorded in the municipal districts further from the city center, especially in the direction to the Václav Havel Airport. There is not a balance in the distribution of beds and tourists across Prague; bed capacities are more dispersed between the city center and the tourist less visited adjacent districts.

The city destinations are characterized by a long tourist season that is less dependent on any particular weather and therefore less connected to any particular part of the year. In Prague, Vienna, and Budapest tourism is concentrated mainly in the spring and summer months. The largest amount of tourists arrive to these cities in April, May, July, and August, while the lowest amount of tourists is recorded in the months of January, February, and November. Tourism is the most evenly distributed across the year in Vienna and the least evenly in Budapest. The development of overnight stays in accommodation establishments between 2003 and 2011 indicates a long-term trend towards a more equal distribution of tourism among the months of the year. The least attractive months for tourists in the surveyed cities have continuously been November and February. These findings indicate a need to develop new and effective products that would attract more tourists in these months. For instance, the ball season may have the potential to bring more tourists in February or November to Prague.

The analysis of tourism in Prague compare to tourism in Vienna and Budapest indicate that Prague has achieved a significant position among these cities, which deserve greater attention in both tourism research and in the sectors concerned with planning and managing the city. The tourism intensity indicators refer to overload of tourism in Prague, especially in its historic center. In particular, congestions, tourist inflation, and overall touristification can be observed in such areas as the Royal Path. Moreover, the numbers of tourists are still increasing. The Royal Path and the entire Old City and Lesser Town are losing their original values of residential area and transforming itself into a tourism ghetto. The development of tourism in Prague is not sustainable in a long term and if this negative development continuous without proper regulation, Prague will be sooner as later faced with the effect of tourism trap.

\section{Acknowledgment}

This article was supported by the project Specific University Research at Charles University in Prague, Faculty of Science, no. 260082. 


\section{References}

Ark, L. A. van der, \& Richards, G. (2006). Attractiveness of cultural activities in European cities: A latent class approach. Tourism Management, 27, 1408-1413. DOI: 10.1016/j.tourman.2005.12.014.

Ashworth, G. J. (2009). Questioning the Urban in Urban Tourism. In G. Maciocco \& S. Sereli (Eds.), Enhancing the Cities: New Perspectives for Tourism and Leisure. Urban Landscape and Perspectives (pp. 207-220). London, UK: Springer.

Asworth, G. J., \& Page, S. J. (2011). Urban tourism research: Recent progress and current paradoxes. Tourism Management, 32 (1), 1-15. DOI: 10.1016/j.tourman.2010.02.002

Ashworth, G. J., \& Tunbridge, J. E. (1990). The tourist-historic city. 1st ed. London, New York: Belhaven Press.

Borg, J. van der, Costa, P., \& Gotti, G. (1996). Tourism in European Heritage Cities. Annals of Tourism Research. 23 (2), 306-321. DOI: 10.1016/0160-7383(95)00065-8.

Berg, L. van den, Borg, J. van der, \& Meer, J. van der (1995). Urban tourism: performance and strategies in eight European cities. European Institute for Comparative Urban Research. 3rd ed. Avebury, UK.

Castillo-Manzano, J. I., López-Valpuesta, L., \& González-Laxe, F. (2011). The effects of the LCC boom on the urban tourism fabric: The viewpoint of tourism managers. Tourism Management, 23 (5), 1085-1095. DOI: 10.1016/j.tourman.2010.09.008.

Clift, S., \& Carter, S. (Eds.). (2000). Tourism and Sex: Culture, Commerce and Coercion. 1st ed. London, UK: Biddles Ltd., Guildford \& King's Lynn.

Cooper, C., \& Morpeth, N. (1998). The impact of Tourism on Residential Experience in Centraleastern Europe: The Development of a New Legitimation Crisis in the Czech Republic. Urban Studies, 35 (12). DOI: 0042-0980 /98/122253-2 3.

Čermáková, D. (2012). Podnikání migrantů v Praze: případová studie Královská cesta. In M. Ouředníček \& J. Temelová (Eds.), Sociálni proměny pražských čturtí (pp. 116-135). Praha: Academia.

Doxey, G. V. (1975). A causation theory of visitor-resident irritants: Methodology and research inferences. In Travel and Tourism Research Associations Sixth Annual Conference Proceedings (pp. 195-98). San Diego, September.

Dumbrovská, V. (2013). Vývoj postaveni Prahy - destinace cestovního ruchu ve středoevropském prostoru (Development of the Status of Prague - Tourism Destination in the Central European Space). Master's Theses. Prague: Charles University in Prague. Faculty of Science. Department of Social Geography and Regional Development. $131 \mathrm{p}$.

Dunne, G., Flanagan, S. \& Buckley, J. (2010). Towards an Understanding of International City Break Travel. International Journal of Tourism Research, 12 (5), 409-417. DOI: 10.1002/jtr.760.

Dunne, G., Flanagan, S., \& Buckley, J. (2011). Towards a Decision Making Model for City Break Travel. Journal of Culture, Tourism and Hospitality Research, 5 (2), 158-172. DOI: $10.1108 / 17506181111139573$.

Edwards, D., Griffin, T., \& Hayllar, B. (2008). Urban Tourism Research: Developing an Agenda. Annals of Tourism Research, 35 (4), 1033-1052. DOI:10.1016/j.annals.2008.09.002.

Fainstein, S. S., \& Judd, D. R. (1999). Global Forces, Local Strategies and Urban Tourism. In D. R. Judd \& S. S. Fainstein (Eds.), The Tourist City (pp. 1-20). 1st ed. New Haven, CT: Yale University Press. 
Judd, D. R., \& Fainstein, S. S. (Eds.). (1999). The Tourist City. 1st ed. New Haven, CT: Yale University Press.

Getz, D. (1993). Planning for Tourism Business Districts. Annals of Tourism Research, 20 (1), 583600. DOI: 0160-7383/93.

Hall, D., Smith, M., \& Marciszewska, B. (2006). Introduction. In D. Hall, M. Smith \& B. Marciszewska (Eds.), Tourism in the New Europe: The Challenges and Opportunities of EU Enlargement (pp. 1-17). 1st ed. Oxfordshire, UK: CAB International.

Hayllar, B., \& Griffin T. (2005). The precinct experience: a phenomenological approach.Tourism Management, 26, 517-528. DOI: 10.1016/j.tourman.2004.03.011.

Hayllar, B., Griffin, T., \& Edwards, D. (Eds.). (2008). City Spaces - Tourist Places: Urban Tourism Precincts. 1st ed. Oxford, UK: Elsevier Ltd.

Hoffman, L. M., Fainstein, S. S. \& Judd, D. R. (Eds.). (2003). Cities and Visitors: regulating people, markets, and city space. 1st ed. Malden, MA: Blackwell Publishing Ltd.

Hoffman, L. M., \& Musil, J. (2009). Prague, Tourism and the Post-industrial City. A Great Cities Institute Working Papers. No. GCP-09-05. Great Cities Institute: University of Illinois at Chicago.

Judd, D. R. (2003). Visitors and the Spatial Ecology of the City. In L. M. Hoffman, S. S. Fainstein \& D. R. Judd (Eds.), Cities and Visitors: regulating people, markets, and city space (pp. 23-38). 1st ed. Malden, MA: Blackwell Publishing Ltd.

Judd, D. R., \& Feinstein, S. S. (Eds.). (1999) The Tourist City. 1st. ed. New Haven, CT: YaleUniversity Press.

Law, C. M. (1993). Urban Tourism: Attracting Visitors to Large Cities. 1st ed. London,UK: Mansell Publishing Limited.

Maitland, R. (2010). Introduction: National Capitals and City Tourism. In R. Maitland \& B. W. Richie (Eds.), City Tourism: National Capital Perspectives. 1st ed.Wallingford, Oxfordshire, UK: CABI c2009.

Maitland, R., \& Richie, B. W. (Eds.). (2010). City Tourism: National Capital Perspectives. 1st ed. Wallingford, Oxfordshire, UK: CABI c2009.

Mazanec, J. A., \& Wöber, K. W. (Eds.). (2010). Analysing International City Tourism. 2nd ed. Wien: Springer.

Metro-Roland, M. M. (2011). Tourist, Sings and the City: The Semiotics of Culture in an Urban Landscape. 1st ed. Farnham, UK: Ashgate Publishing Limited.

Page, S. (1995). Urban Tourism. 1st ed. London: Routledge.

Page, S. (2002). Urban tourism: Evaluating tourist' experience of urban places. In C. Ryan (Ed.), The Tourist Experience (pp. 112-136). 2nd ed. London, UK: Thomson Learning.

Pásková, M. (2012). Environmentalistika cestovního ruchu. Czech Journal of Tourism, 1 (2), 77-113.

Pásková, M., \& Zelenka, J. (2002). Cestovni ruch: výkladový slovnik. 1. vyd. Praha: MMR ČR.

Pearce, D. G. (1998). Tourism development in Paris: Public Intervention. Annals of Tourism Research, 25 (2), 457-476.

Pearce, D. G. (2001). An Integrative Framework for Urban Tourism Research. Annals of Tourism Research, 28 (4), 926-946.

Popp, M. (2011). Positive and Negative Urban Tourist Crowding: Florence, Italy. Tourism Geographies: An International Journal of Tourism Space, Place and Environment, 14 (1), 50-72. DOI: $10.1080 / 14616688.2011 .597421$. 
Puczkó, L., Rátz, T., \& Smith, M. (2007). Old City, New Image: Perception, Positioning and Promotion of Budapest. Journal of Travel and Tourism Marketing, 22 (3/4), 21-34. DOI: 10.1300/ J073v22n03_03.

Simpson, F. (1999). Tourist Impact in the Historic Centre of Prague: Resident and Visitor Perceptions of the Historic Built Environment. The Geographical Journal, 165 (2), 173-183. DOI: $10.2307 / 3060415$.

Šauer, M., \& Holešinská, A. (in press). Transformation of global cities - urban tourism and branding: Prague perspective. In Proceedings of the ATLAS Annual Conference London, 2012. Arnhem: ATLAS.

Thurnell-Read, T. (2012). Tourism space and place: British Stag Tourism in Poland. Annals of Tourism Research, 39 (2), 801-819. DOI: 10.1016/j.annals.2011.09.009

Trew, J., \& Cockerell, N. (2002). The European market for UK city breaks. Tourism Insights, 14 (58), 85-111.

\section{Sources}

Cestovni ruch (2013) [online]. ČSÚ. Praha: Krajská správa ČSÚ v hl. m. Praze, c2013, poslední aktualizace 12. 2. 2013 [cite 2013-12-20]. Retrieved from <http://www.czso.cz/x/krajedata.nsf/ oblast2/cestovni_ruch-xa>.

City tourism: Nights and arrivals (2013) [online]. Austrian National Tourist Office. Vienna: TouMIS [cite 2013-03-17]. Retrieved from 〈http://www.tourmis.info/cgi-bin/tmintro.pl>.

Euromonitor (2012). Top 100 Cities Destination Ranking [online]. January 21 [cite 12-20-2013]. Retrieved from <http://blog.euromonitor.com/2013/01/top-100-cities-destination-ranking. html>.

ICCA (2012). Statistic Report 2002-2011: International Association Meetings Market [PDF]. Amsterdam: ICCA [cite 12-20-2013]. Retrieved from <http://www.iccaworld.com/npps/section. cfm?SID=12>.

Statistik Wien (2013) [online]. Wien: Magistrat der Stadt Wien [cite 2013-12-17]. Verfügbar bei <http://www.wien.gv.at/statistik/>.

Tables (STADAT) - Themes: Regional statistic (2013) [online]. Budapest: HCSO [cite 2013-12-07]. Retrieved from 〈http://www.ksh.hu/engstadat>.

Travel and Leisure magazine (2013). World Best Awards 2013 [online]. Time Inc. Affluent Media Group [cite 2013-12-07]. Retrieved from <http://www.travelandleisure.com/worldsbest/2013/ cities/europe-cities/504>.

Trip Advisor (2013). Travelers'Choice Awards 2013 [online]. TripAdvisor LLC [cite 2013-12-15]. Retrieved from 〈http://www.tripadvisor.com/TravelersChoice-Destinations-cTop-g4>.

UNWTO (2012). Annual Report 2011 [online]. Madrid: UNWTO [cite 12-20-2013]. Retrieved from <http://dtxtq4w60xqpw.cloudfront.net/sites/all/files/pdf/annual_report_2011.pdf>.

Urban Audit: main tables (2013) [online]. Luxembourg: European Commission: Eurostat, last update 6. 1. 2013 [cite 2013-12-07]. Retrieved from <http://epp.eurostat.ec.europa.eu/portal/ page/portal/region_cities/city_urban/data_cities/Figures_sub1>. 